\title{
The Nxaunxau kimberlites of northwest Botswana
}

\author{
De Wit MCJ, Hiyoveni RT, Kahari M, Bruchs J
}

Tsodilo Resources Ltd, Toronto, Ontario, Canada

\section{Introduction}

The Nxaunxau kimberlites in northwest Botswana are part of the Xaudum kimberlite province that extends into northeast Namibia. The province comprises 45 known kimberlites of which 31 , the Nxaunxau bodies, occur in Botswana, and the others, seven in the Kaudom South cluster, four near Sikereti and two in the Gura cluster, occur in Namibia (De Wit, 2013).

\section{Exploration history}

The Xaudum kimberlite province straddles the Botswana/Namibian border just south of the Caprivi strip and roughly $250 \mathrm{~km}$ northwest of Maun. All the known kimberlites in this province, apart from the two Gura bodies, are situated within the easterly directed Xaudum drainage. The first kimberlites of this province, the Sikereti bodies, were found in 1979 in Namibia by De Beers using soil sampling. These four kimberlites were classified as Group-1 diatremes and both tuffisitic (TKB) and magmatic (aphanitic and macrocrystic varieties) rock-types are present. No macrodiamonds were produced from the bulk sampling and only three microdiamonds were recovered from one of the kimberlites (Winter and Rikhotso, 1998). The Ashton Mining/Reunion Mining joint venture discovered 18 of the kimberlites in Botswana, close to Nxaunxau, in 1998. These were found using the Botswana government aeromagnetic data that was started in 1998 on $250 \mathrm{~m}$ spaced north-south orientated flight lines with the sensor some $70 \mathrm{~m}$ above the ground. From 2002 onwards exploration by Tsodilo Resources Ltd discovered an additional 13 kimberlites and increased the number of discoveries in the Nxaunxau cluster to 31, with the last kimberlite being drilled in 2011. All of these also belong to the Group-1 variety. In 2004 and 2005 eight more kimberlites were discovered north of the Sikereti pipes in Namibia by Motapa Diamonds and are referred to as the Kaudom South cluster. Around $70 \mathrm{~km}$ south of the Sikereti kimberlites, around 2000, Mount Burgess found two small kimberlites, Gura 1 and Nxaon, and one para-kimberlite called Rabbit. Judging from the geographical distribution of the 45 kimberlites, it is suggested that the Nxaunxau, Kaudom South and Sikereti clusters form part of one field of 43 occurrences: here referred to as the Xaudum kimberlite province. The Gura 1 and Nxa-on kimberlites, some distance to the south, probably form a separate cluster, and the Rabbit para-kimberlite may be a different event altogether. The continued interest in the region is based on yet unresolved kimberlitic mineral anomalies in Namibia, containing both high-interest garnets and diamonds, occurring proximal to these kimberlites. In addition, deep penetrating magnetotelluric surveys, carried out in the area between 2005 and 2006, showed that northwest Ngamiland is underlain by resistive lithosphere which appears to be part of the Congo Craton (Khoza, 2013). This was further confirmed by Tsodilo which drilled basement rocks of Archean ages in the immediate vicinity (www.tsodiloresources.com).

\section{Regional geology}

On a local scale the Nxaunxau kimberlites have intruded Neoproterozoic carbonates of the Ah-a Hills Formation, which are covered by remnants of Mulden Group phyllites/psammites of Cambrian age, and Karoo Supergroup sediments, and are intruded by Karoo dolerites. Lower Karoo sediments are preserved in deep vallyes. Continued exploration has shown that the meta-sediments of the Damara orogeny have been thrusted over the southern edge of the Congo Craton basement. The kimberlites are also spatially associated with the NW-SE trending Botswana dyke swarm of Jurassic age, although preKaroo dolerites are also present in the area. These cover sequences provided a wide variety of the crustal xenoliths within the kimberlite with commonly Damara carbonate and Karoo Supergroup tillites, shales, sandstones and dolerite. Xenoliths of the possibly basal Kalahari Group sediments have been described within the Nxaunxau kimberlites (De Wit, 2013) and the Sikereti bodies (Balfour, 1985). The Nxaunxau kimberlites are covered by Kalahari Group sediments of up to $30 \mathrm{~m}$ in thickness. 


\section{Age of kimberlite event}

A kimberlite event has been dated at $83.2 \pm 1.2 \mathrm{Ma}$, based on U-Pb dating of perovskite from three of the kimberlites: K20, K21 and K22 (Batumike et al., 2007). This was confirmed by Leong (2014) who obtained U-Pb perovskite ages for kimberlites K20, K21, K22 and K25 from samples of greater than $100 \mathrm{~m}$ depths. Some of the grains were large as $100-200 \mu \mathrm{m}$ and fresh. Although thin bands of phlogopite in $\mathrm{K} 8$ appeared enough for ${ }^{40} \mathrm{Ar} /{ }^{39} \mathrm{Ar}$ dating method, the U-Pb perovskite dating gave the most robust and precise age of $84 \pm 4 \mathrm{Ma}$ (Leong, 2014).

This relatively young age is supported by the presence of crustal xenoliths of Kalahari basal conglomerate and calcretes. It therefore also suggests that the base of the Kalahari in north-west Botswana is at least Late Cretaceous in age.

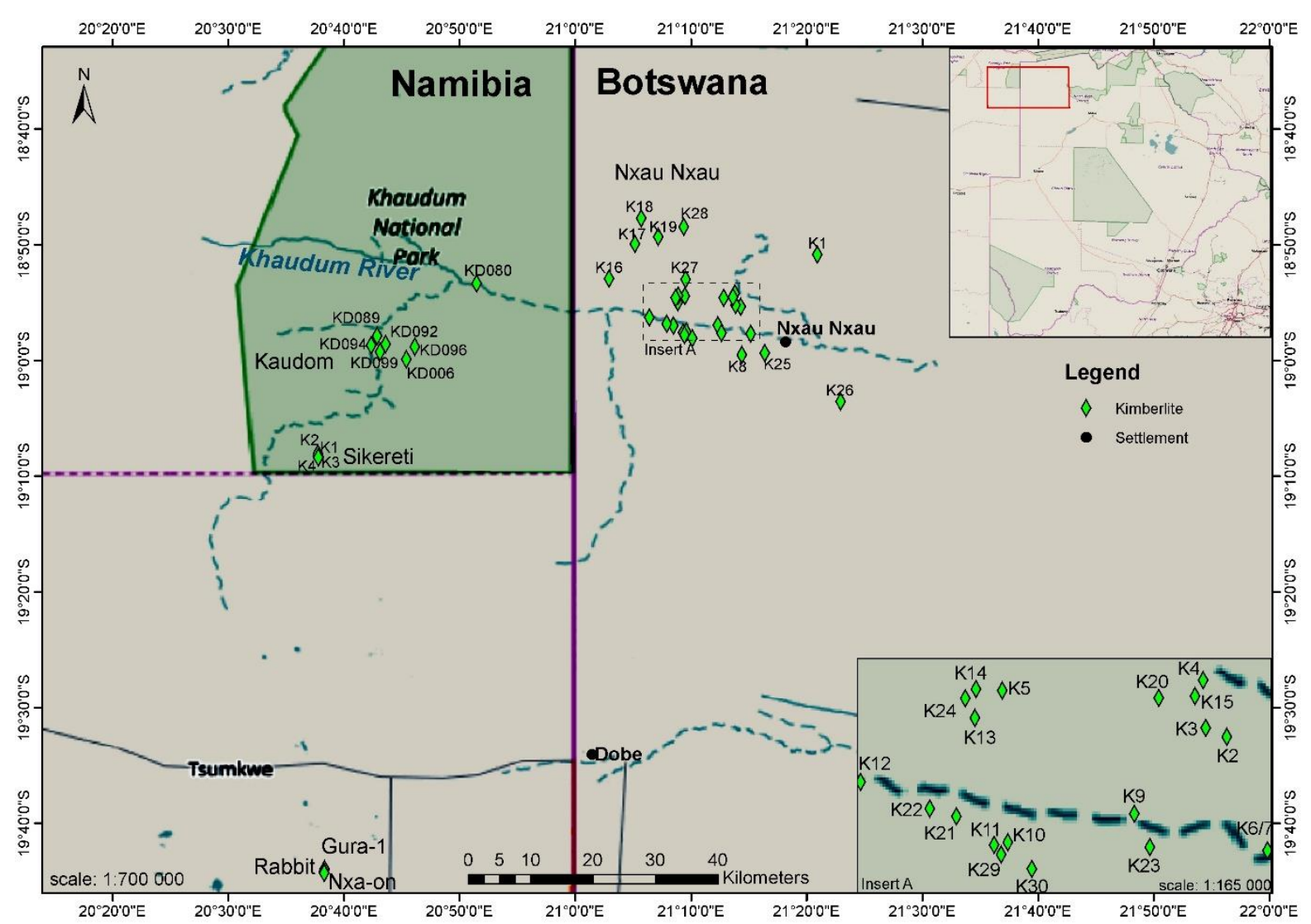

Figure 1. Locality map for the Khaudum kimberlite province straddling the Namibian/Botswana border.

\section{Petrography}

From a petrographic point of view the Nxaunxau kimberlites range from volcaniclastic (re-sedimented and pyroclastic kimberlite) to coherent (hypabyssal) kimberlite. Serpentinized olivines, ilmenite and phologopites form the main macro constituents of the kimberlite set in a groundmass of perovskites, atoll textured spinels, calcite and serpentine. Although this province has been shown to be diamondiferous with micro-diamonds recovered from four of six Nxaunxau kimberlites tested, its low counts, and the garnet mineral chemistry, which indicate that these are mainly of lherzolitic paragenesis dominated by G9 and G5 varieties, supports the conclusion that from an economic point of view these kimberlites have so far not warranted any further evaluation.

The Nxaunxau kimberlites are highly altered; displaying an assortment of textures and diverse mineralogy ranging from volcaniclastic to coherent. The volcaniclastic kimberlite is highly fragmented and contains abundant angular xenoliths, such as dolerite, limestone, shale and biotite amphibolites, rounded magma clasts, including peletal lapilli, and abundant macrocrysts, ilmenite and garnet, irregularly distributed throughout the rock (Hiyoveni, 2015). The matrix is highly altered to clay minerals and calcite and some of the samples contain spinels, atoll textured titanomagnetite and highly 
altered perovskites. The coherent kimberlites have inequigranular texture and are typically macrocrystic. Some of the samples display segregationary texture with pools of interstitial calcite between olivine phenocrysts (Leong, 2014). Olivine macrocrysts are abundant with rare ilmenite macrocrysts. Matric minerals are fine-grained and serpentinised or altered to calcite. Common groundmass minerals include perovskite and titanomagnetite and Leong (2014) observed very rare apatite in a sample from K21.

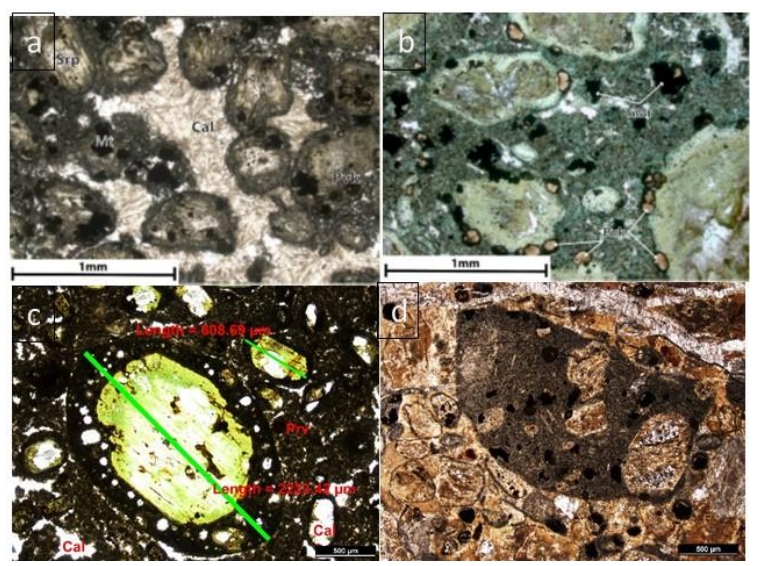

Figure 1. a) Macrocrystic coherent kimberlite with segregationary texture. b) Coherent kimberlite with olivine macrocrysts and perovskite grains. c) Volcaniclastic kimberlite with peletal lapilli. d)

Volcaniclastic kimberlite with magma clasts with altered olivine inclusions.

The kimberlites proximal to the Botswana Karoo dolerite dyke swarm were generally the volcaniclastic types and seem to contain a much higher abundance of crystals xenoliths than those located further from dykes.

\section{References}

Balfour DJ, Hegenberger W, Medlycott AS and Wilson KJ (1985) Kimberlites near Sikereti, northeastern South West Africa/Namibia. Communs Geol. Surv. SW Africa/Namibia, 1, 69-77.

Batumike J, Belousova EA and Griffin WL (2007) U-Pb dating of perovskite Nxau Nxau kimberlite, Botswana. Gemoc Report Tsodilo-2007/1, pp 13

De Wit MCJ (2013) The Xaudum kimberlite province straddling the southern margin of the Angolan Craton. Abstract $24^{\text {th }}$ Colloqium of African Geology, $8^{\text {th }}-14^{\text {th }}$ Janunary 2013, Ethiopia, pp 1

Hiyoveni RT (2015) Characterization of (K29, K30) Nxaunxau kimberlites. Unpubl. BSc thesis. University of Botswana, Botswana, pp 47

Khoza TD, Jones AG, Muller MR, Evans RL, Miensopust MP and Webb SJ (2013) Lithospheric structure of an Archean craton and adjacent mobile belt revealed from 2-D and 3-D inversion of magnetotelluric data: Example from southern Congo craton in northern Namibia. J. Geophys. Res: Solod Earth, vol. 118, 1-20

Leong HX (2014) Petrology of the Nxau Nxau Kimberlites, northwest Botswana. Unpubl. MSc thesis. University of Melbourne, Australia, pp 78

Winter F and Rikhotso CT (1998) Final report on CDM Exploration activities in north-eastern Namibia. Open File Geol. Surv. Namibia, Report No. KR/98/0476, pp 51 